\title{
IMPACTUL METODELOR ACTIVE ASUPRA PREDĂRII RELIGIEI
}

\author{
Gheorghe Acatrinei \\ Irina Roxana Acatrinei *
}

\begin{abstract}
Religion, as a school subject, has a strong formative nature, with effects on long-term in the child or teenager becoming. In the achievement of the educational process, the Religion teacher may use methodical diversified resources, through which he creates his own teaching style. The use of teaching and learning methods with an activated size seems necessary for creating a student-centered teaching style. To achieve the aims, the teacher is free to choose the most appropriate methods, whether modern or traditional. Since the design stage, Religion class can acquire an activated size by selecting the most appropriate teaching strategies and the types of lessons organisation.
\end{abstract}

Keywords: activated methods, types of lesson, religious education, learning content.

\section{Metodele didactice - căi de realizare a educației}

Una dintre marile realizări ale societăţii post-decembriste este reintroducerea Religiei ca disciplină de studiu în învățământul românesc, la nivel primar, gimnazial și liceal. Biserica Ortodoxă Română s-a implicat semnificativ, printre altele, și în pregătirea cadrelor didactice care urmau să predea Religia, prin înființarea secțiilor de teologie didactică în cadrul facultăților de teologie, în întocmirea curriculumului obligatoriu, prin aprobarea unor lucrări metodice, manuale și auxiliare didactice care să susţină activitatea didactică de la clasă. Toate aceste aspecte, precum și interesul pentru cercetarea pedagogică a unor distinși profesori și valorificarea acestora, prin publicarea unor lucrări de specialitate, au imprimat disciplinei Religie un caracter modern, într-un timp relativ scurt.

* Teachers, Gymnasial School Cornu Luncii, Suceava, Romania. 
Menținerea disciplinei Religie în școala românească depinde, în egală măsură, de finalitățile acesteia pe termen lung, raportate la realitățile socio-culturale naționale, europene și globale, precum și de maniera în care Religia reușește să se impună în trunchiul comun ca o disciplină actuală, modernă și flexibilă. Conținuturile disciplinei în sine nu asigură această atractivitate și nici baza materială pe care profesorul de religie o are la îndemână. Dascălul poate imprima disciplinei Religie un caracter modern, prin dezvoltarea unui stil didactic centrat pe elev, prin valorificarea cunoștințelor și experienței personale a elevilor în cadrul procesului de învățare, prin transformarea elevului din spectator al actului educativ, în actor sau coautor al propriei formări spirituale.

Modernizarea disciplinei Religie nu înseamnă doar înlocuirea conținuturilor, ci și predarea lor prin strategii didactice care să urmărească activizarea elevilor. Poate cea mai mare provocare pentru orice cadru didactic constă în îmbinarea fericită a metodelor de predare-învățare moderne cu cele tradiționale, în abordarea conținuturilor, având drept scop atingerea unor finalități în plan cognitiv, volițional și atitudinal.

În şcoala modernă, dimensiunea de bază în funcţie de care sunt apreciate metodele de învățământ este caracterul lor activ, adică măsura în care sunt capabile să declanşeze angajarea elevilor în activitate. Din această perspectivă, lucrările de specialitate abundă în clasificări ale acestor metode numite fie active, fie activ-participative, fie interactive, fie moderne. Sintagma „,metode activizante” este prezentă în lucrările unor distinși profesori și tinde să se impună în pedagogia românească în locul expresiei ,metode activizatoare”, motiv pentru care am utilizato. Având în vedere aspectul activizării elevilor în cadrul procesului de predare-învățare, în studiul de faţă sintagma metode activizante include atât metodele active, cât şi pe cele interactive.

Din punct de vedere etimologic, termenul metodă îşi are originea în limba greacă (metha $=$ spre, şi odos $=$ cale) desemnând o cale de urmat eficientă pentru atingerea anumitor scopuri. Termenul corespondent latin, methodus are acelaşi înţeles - cale, drum, mod de lucru. 
Din perspectivă pedagogică, prin metodă de invăţământ se înţelege o modalitate de acţiune în vederea realizării unor scopuri. Trebuie precizat că aplicarea metodelor de învăţământ implică în mod necesar atât cadrul didactic, cât şi elevul. Din perspectiva profesorului, metoda apare drept

„o cale de organizare şi conducere a activităţii de cunoaştere (învăţare) a elevului, o cale de conducere înspre construcţia cunoaşterii individuale a acestuia, un instrument didactic cu ajutorul căruia îi determină pe cei aflaţi în băncile şcolii la un demers de asimilare activă a unor noi cunoştinţe şi forme comportamentale, de stimulare, în acelaşi timp, a dezvoltării forţelor lor cognitive, intelectuale"1.

Pentru elev metoda apare ca „drumul pe care acesta il parcurge de la necunoaştere la cunoaştere; calea care îl conduce de la o cunoaştere mai puţin profundă spre una mai adâncă" ${ }^{2} . \mathrm{Cu}$ alte cuvinte, metoda reprezintă ,un mod de a proceda care tinde să plaseze elevul într-o situaţie de învăţare, mai mult sau mai puţin dirijată"’3.

Metodologia didactică desemnează ansamblul metodelor de predare şi învăţare utilizate. Ea studiază natura, funcţiile, statutul şi clasificarea metodelor de învăţământ, evidenţiind principiile de utilizare eficientă a acestora în organizarea şi desfăşurarea procesului de predare - învăţare - evaluare.

Metodele de învăţământ sunt un element de bază al strategiilor didactice, în strânsă relaţie cu mijloacele de învăţământ şi cu modalităţile de grupare a elevilor. De aceea, opţiunea pentru o anumită strategie didactică condiţionează utilizarea unor metode de învăţământ specifice.

Strategia didactică poate fi definită drept ,un ansamblu de procedee prin care se realizează conlucrarea dintre profesor şi elevi în

\footnotetext{
${ }^{1}$ Ioan Cerghit, Metode de învăţământ, ediţia a IV-a, Iaşi, Edit. Polirom, 2006, p. 17.

${ }^{2}$ Ibidem, p. 17.

${ }^{3}$ Iucu Romiţă, Instruirea şcolarăa, Iaşi, Edit. Polirom, 2001, p. 142.
} 
vederea predării şi învăţării unui volum de informaţii, a formării unor priceperi şi deprinderi, a dezvoltării personalității umane" ${ }^{\text {. }}$

Totodată, metodele de învăţământ fac parte din condiţiile externe ale învăţării, care determină eficienţa acesteia. De aici decurge importanţa alegerii judicioase a metodelor corespunzătoare fiecărei activităţi didactice.

\section{Tradiţional şi modern în metodologia didactică}

Trăim într-o societate în permanentă schimbare. Inevitabil, aceste schimbări se reflectă şi asupra educaţiei, în general, şi a învăţământului, în special. Au loc transformări rapide evidenţiate, în primul rând, de crearea mediului de învăţare; de cele mai multe ori, acesta favorizează tehnicile de învăţare şi de muncă intelectuală. Educaţia modernă este caracterizată de schimbare, inovare şi dinamism şi, privită din perspectiva elevului, trebuie să demonstreze afirmaţia: , $A$ şti ce să faci cu ce ai învătat". ${ }^{5}$ Rolul profesorului s-a schimbat. Din actor principal al lecţiei, el devine ghid şi facilitator al proceselor de invăţare, în cadrul cărora elevul este actorul principal. Prin activităţile întreprinse, profesorul dă dovadă de creativitate şi inovare permanentă. Acest fapt este luat ca exemplu de către elevi; şi ei vor deveni treptat creativi, la fel ca şi dascălii lor, urmându-le exemplul.

Pedagogia modernă pune mare accent pe învăţarea experienţială. Elevul este antrenat în activităţi stimulative în vederea valorizării şi dezvoltării propriului potențial, dar cu respectarea ritmului şi stilului propriu de învăţare.

Mai mult ca niciodată, demersul proiectiv al lecţiilor presupune timp pentru a diversifica ideile, a descoperi noi valori, a angaja în acţiuni, a căpăta încredere în capacităţile personale pentru a le aplica şi valorifica creator, toate având acelaşi scop - de a eficientiza procesul instructiv-educativ.

\footnotetext{
${ }^{4}$ Ioan Nicola, Pedagogie, ediţia a II-a, Bucureşti, Edit. Didactică şi Pedagogică, R.A., 1994, p. 307.

${ }^{5}$ Silvia Breben, Metode interactive de grup. Ghid metodologic, Craiova, Edit. Arves, 2002, p. 11.
} 
Ce a fost tradiţional şi a devenit modern? Tradiţional, conţinutul de învăţare era transmis elevului în stare finită; el trebuia doar să-1 asimileze şi să-1 utilizeze în rezolvarea unor sarcini concrete. Modern, elevul este pus în situaţia de a descoperi singur forma finită a conţinutului prin acţiuni concrete, bine organizate, şi apoi de a-l aplica în rezolvarea unor noi sarcini de învăţare, care permanent vor urmări descoperirea unor noi adevăruri.

Sursa cunoştinţelor este văzută de didactica tradiţională în percepție, în timp ce didactica modernă, în acţiunea externă sau mentală; „celula” gândirii este imaginea - cunoaşterea este actul de copiere al realităţii - pentru tradiţionalişti, iar pentru modernişti, este operaţia - cunoaşterea este reflectarea activă a realului; tradiţional, elevul este obiect al educaţiei, receptor de informaţii gata pregătite, în timp ce modernul îl percepe ca subiect al educaţiei, ce primeşte informaţiile prin efort propriu, dar ghidat ${ }^{6}$.

Alegerea şi combinarea cu succes a celor $3 \mathrm{M}$ menţionaţi anterior lasă deplină libertate profesorului modern. Ele nu sunt reţete fabricate, preconcepute, ci, dimpotrivă, alegerea lor se face în funcţie de experienţa profesorului şi al elevului, particularităţile întregii clase de elevi şi a materialului de predat.

Învăţământul modern presupune o îmbinare echilibrată între munca individuală şi lucrul în echipă. La rândul lor, aceste modalităţi de lucru sunt susţinute de metodele activ-participative, respectiv de metodele interactive. Inevitabil, ,formaţia trece inaintea instrucţiei, iar dezvoltarea capacităţilor intelectual-acţionale şi a proceselor mintale ale elevului trece înaintea transmiterii de cunoştinţe, fără însă a le neglija" ". Schimbările enunţate determină schimbări ale orientării metodologice - centralizarea ei pe elev, dar respectând particularităţile acestuia şi ritmul său propriu de învăţare. Este primul atu al învățământului modern, şi anume acela de a oferi şanse egale tuturor elevilor.

\footnotetext{
${ }^{6}$ A. Dancsuly, Pedagogie, Bucureşti, Edit. Didactică şi Pedagogică, 1979, p. 149.

${ }^{7}$ Ioan Cerghit, Metode de invățământ ..., p. 67.
} 
Echilibrul dintre munca individuală şi munca în echipă este menţinut şi în cadrul aplicării metodelor activ-participative şi a celor interactive. S-au dezvoltat astfel două orientări metodologice distincte:

- metodele activ-participative ce urmăresc diferenţierea, individuali-zarea şi personalizarea proceselor de instruire, şi

- metodele interactive, bazate pe interacţiunile şi interrelaţiile din cadrul grupului, ce vizează socializarea proceselor de instruire.

Metodele activ-participative se bazează pe ideea că învăţarea este o activitate personală, proprie fiecărui individ. Ele evidenţiază caracterul idiosincretic (idios $=$ propriu, specific) al învăţării ${ }^{8}$ - este o activitate ce depinde de particularităţile celui ce învaţă. Se dezvoltă astfel o metodologie centrată pe elev şi pe propria-i acţiune.

Învăţarea figurativă ce promova activităţi de ascultare, receptare, repetare, memorizare, reproducere este înlocuită de învăţarea activă ce antrenează spontaneitatea, imaginaţia, operaţiile gândirii; „este activitatea prin care contactul subiectului cu noul material este transformat într-o experienţă activă, trăită de el" ". Însuşi Piaget promova ideea învăţării active prin directa acţiune a elevului asupra realităţii: „A cunoaşte un obiect înseamnă a acţiona asupra lui şi a-l transforma spre a sesiza mecanismele acestei transformări in legătură cu acţiunile transformatoare însăşı ${ }^{\prime \prime 10}$.

Formele active ale învăţării sunt învăţarea euristică (explorativă), învăţarea prin rezolvarea de probleme (rezolvarea alternativelor), învăţarea prin acţiune (learning by doing). Elevul activ este elevul care gândeşte, adună şi organizează idei, reflectă asupra lor, prelucrează şi sintetizează, asociază, caută soluţii, întreprinde o acţiune mintală de căutare, de cercetare şi redescoperire a adevărurilor, de

\footnotetext{
${ }^{8}$ Ibidem, p. 68.

${ }^{9}$ D. P. Ausubel, apud Ioan Cerghit, Metode de învăţământ ..., p. 71.

${ }^{10}$ Dumitru Călugăru apud Prof. Elena Guţă, Proiectarea didactică - instrument eficace de evitare a improvizatiei în procesul instructiv-educativ, în „Dimensiuni ale educaţiei la început de mileniu - studii, articole, soluții didactice”, Iași, Edit. Infoed XXI, 2007, p. 168.
} 
elaborare a noilor cunoştinţe ${ }^{11}$. Având în vedere toate aceste aspecte, rolul şi misiunea profesorului se schimbă - el va căuta acele căi prin care va stimula dorinţa elevilor de a descoperi şi dobândi cunoştinţele, printr-o activitate cât mai activă. Pentru elev, activitatea desfăşurată în clasă devine o adevărată aventură învăluită în mister - un mister didactic - îndrăznim să-i spunem, iar el, un erou chemat să dezlege enigmele.

Misiunea profesorului este de a-1 activiza pe elev, a-1 pune în faţa unor situaţii prin care el să descopere ce este nou, dar şi să-şi dezvolte şi să-şi stimuleze capacităţile intelectuale şi afective. Activizarea elevilor este privită drept

„o suită de acţiuni:

- stimularea şi cultivarea interesului elevilor pentru cunoaştere

- valorificarea inteligenţei elevilor şi a celorlalte funcţii psihice ale acestora prin efortul pe care îl depun

- formarea şi exersarea la elevi a capacităţii de însuşire a cunoştinţelor

- formarea şi exersarea la elevi a abilităţilor de orientare autonomă în probleme practice

- cultivarea spiritului investigativ, a căutărilor personale şi a atitudinii epistemice prin antrenarea elevilor în organizarea, conducerea, desfăşurarea şi evaluarea activităţii didactice şcolare şi extraşcolare" ${ }^{12}$.

Profesorul utilizează în activitatea didactică metode activparticipative, conştient fiind noţiunea de „învăţare" diferă de la un elev la altul. Unii pun mai multă atenţie pe puterea memoriei (operaţiile de memorare şi de înţelegere), alţii pe gândirea productivă (capacitatea de a pune şi de a rezolva probleme prin gândire convergentă, prin gândire divergentă sau prin gândire evaluatoare); unii apelează la aptitudini creatoare, alţii la gândirea critică sau la capacitatea de reflecţie ${ }^{13}$.

\footnotetext{
${ }_{11}^{11}$ Ibidem, p. 71.

${ }^{12}$ Miron Ionescu, Ioan Radu (coord.), Didactica modernă, Cluj-Napoca, Edit. Dacia, 1995, p. 135.
}

${ }^{13}$ A. Pare, L. Pelletier, apud Ioan Cerghit, Metode de învătăământ..., p. 69. 
Potenţialul intelectual al elevului este pe deplin dezvoltat dacă se realizează favorabil echilibrul dintre învățarea individuală şi cea interactivă, de grup. Invăţarea interactivă ${ }^{14}$ numită şi învăţarea prin cooperare sau colaborare se bazează pe schimbul de idei şi informaţii, impresii şi atitudini, confruntarea de opinii şi convingeri, experienţe şi reflecţii, toate având acelaşi scop - construcţia de cunoştinţe noi, identificarea de soluţii noi; este învăţarea prin cooperare (sarcini şi responsabilităţi individuale între membrii grupului, subordonate ţelului comun) şi prin colaborare (roluri şi funcţii diferite, activitate comună).

Învăţarea interactivă este stimulată şi susţinută prin utilizarea metodelor interactive. Pe lângă scopul lor principal de a forma şi consolida deprinderile elevilor de a găsi singuri informaţii, de a lucra în echipă, de a aplica cunoştinţele dobândite în situaţii concrete de viaţă, de a-şi descoperi şi conştientiza propriul stil de învăţare, metodele interactive urmăresc formarea acelor calităţi şi comportamente necesare tânărului pe tot parcursul vieţii: calităţi europene bazate pe atitudini democratice, relaţii interculturale întemeiate pe comunicare, stimularea gândirii productive, a gândirii divergente şi laterale, libertatea de exprimare a cunoştinţelor, a gândurilor şi a faptelor, încurajarea autonomiei elevului, promovarea cooperării ${ }^{15}$. Succesul muncii individuale şi al lucrului în echipă contribuie semnificativ la consolidarea motivaţiei interioare a elevului.

Există o paletă largă de metode interactive, dar utilizarea lor presupune respectarea unor reguli general valabile: respectul reciproc, sinceritate, punctualitate, toleranţă, atitudine pozitivă, confidenţialitate şi discreţie, interzicerea ironiilor şi jignirilor, ascultare celui care vorbeşte, până la terminarea ideii, limbaj adecvat, interdicţia monopolizării discuţiei, dreptul de a nu participa, se analizează faptele, nu persoanele etc ${ }^{16}$.

În practica pedagogică internaţională actuală toate aceste metode sunt denumite generic ca metode sau tehnici de învăţare

\footnotetext{
${ }^{14}$ Miron Ionescu, Ioan Radu (coord.), Didactica modernă..., p. 77.

${ }^{15}$ Silvia Breben, Metode interactive de grup. Ghid metodologic..., p. 26.

${ }^{16}$ E. L. Danciu apud Ioan Cerghit, Metode de învăţământ ..., p. 76.
} 
activă. Aşadar utilizarea acestor metode are ca şi deziderat realizarea învăţării de către elevi într-o manieră activă. Învăţarea activă (active learning) este rezultatul efortului elevului, care devine astfel autor al actului educativ. Profesorul devine doar moderator, de aceea el îşi dezvoltă anumite strategii de predare (teaching strategies), prin care încurajează elevii spre o învăţare activă, prin metode specifice. În limba română folosirea expresiei ,metode active de invăţare” poate duce la raţionamentul eronat că metodele sunt active; metodele sunt doar instrumente folosite de profesor cu un anumit scop, de aceea ele nu pot fi nici active, nici pasive. Atitudinea elevului la lecţie, în raport cu tehnica folosită, poate deveni activă sau pasivă. Adjectivul ,active” se referă la învăţare, nu la metode, ducându-ne cu gândul la finalitatea activităţii didactice, deci învăţarea poate fi activă sau pasivă. Prin urmare o formulare mai fericită în vederea unei înţelegeri corecte ar putea fi „metode de învăţare activă". Sintagma care câştigă tot mai mult teren în pedagogia românească este ,metode activizante de predare-învăţare".

Şi în pedagogia românească se dezvoltă tot mai mult o „didactică a metodelor active"17, ca urmare a rezultatelor obţinute prin cercetări diverse din domeniul psihogenezei cunoştinţelor şi mai ales al ştiinţelor educaţiei. Astfel, prin metode active se înţelege astăzi ,toate metodele care implică în mod real pe cel ce învaţă, ţinând să-l facă pe acesta să-şi construiască singur propria cunoaştere, plecând de la studii de caz, jocuri de rol, situaţii propuse de el sau de formator, în care partea de implicare a celui ce învaţă este puternică" $" 18$.

$\mathrm{O}$ aparentă opoziţie între aspectul tradiţional şi cel modern al sistemului de metode didactice se observă în diferite lucrări de specialitate. Astfel, la cele mai multe cursuri de formare profesională continuă, sistemul metodelor de învăţământ apare format din:

\footnotetext{
${ }^{17}$ Miron Ionescu, Ioan Radu (coord.), Didactica modernă..., p. 129.

18 Pedagogie dictionnaire des concepts cles. Apprentissages formation et psychologie cognitive, apud Crenguţa-Lăcrămioara Oprea, Strategii didactice interactive, ediţia a II-a, Bucureşti, Edit. Didactică şi Pedagogică, R.A., 2007, p. 28.
} 
- metode tradiţionale, cu un lung istoric în instituţia şcolară şi care pot fi păstrate cu condiţia reconsiderării şi adaptării lor la exigenţele învăţământului modern;

- metode moderne, determinate de progresele înregistrate în ştiinţă şi tehnică. Unele dintre acestea de exemplu, se apropie de metodele de cercetare ştiinţifică, punându-l pe elev în situaţia de a dobândi cunoştinţele printr-un efort propriu de investigaţie experimentală; altele valorifică tehnica de vârf (simulatoarele, calculatorul).

În şcoala modernă, dimensiunea de bază în funcţie de care sunt considerate metodele de învăţământ este caracterul lor activ adică măsura în care sunt capabile să declanşeze angajarea elevilor în activitate, concretă sau mentală, să le stimuleze motivaţia, capacităţile cognitive şi creatoare. În acest sens, un criteriu de apreciere a eficienţei metodelor îl reprezintă valenţele formative ale acestora, impactul lor asupra dezvoltării personalităţii elevilor.

\section{Abordarea modernă a metodelor tradiţionale}

Încă de acum patru decenii, profesorul M. Ionescu anticipa că

„în etapa actuală a dezvoltării ştiinţei, procesului de învăţământ îi devin necesare anumite modalităţi noi care să-1 facă mai operativ şi mai uşor racordabil nevoilor vieţii prin perfecţionarea conţinutului şi a tehnicii didactice" $" 19$.

Într-adevăr, procesul de învăţământ se află într-o permanentă transformare şi adaptare la realităţile cotidiene, programele şcolare suferind modificări majore în perioade relativ scurte de timp. Tehnica didactică, de asemenea, se află într-un continuu proces de adaptare la nou, cercetările întreprinse în diferite domenii şi în special în cel al educaţiei, conducând la apariţia de noi strategii didactice bazate pe metode diverse, unele mai noi, altele cu un istoric impresionant.

\footnotetext{
${ }^{19}$ Miron Ionescu, Clasic şi modern în organizarea lecţiei, Cluj, Edit. Dacia, 1972, p. 177.
} 
Adaptarea şi transformarea metodologiei didactice nu înseamnă automat renunţarea la metodele tradiţionale, socotindu-le ,învechite". Dintr-o analiză istorică a metodelor, se observă că anumite metode, vechi de secole, au căzut în dizgraţie în anumite perioade, dar au fost reluate şi valorificate în alte etape. Studiul de caz, conversaţia, studiul individual, repetitita ş.a. sunt metode folosite în antichitate, abandonate timp de secole şi redescoperite şi folosite la scară globală în zilele noastre. Aşadar, nu neapărat tot ceea ce este vechi este şi demodat, şi nu tot ceea ce este modern şi nou este, invariabil, şi bun, sau eficient.

Învăţământul modern încurajează folosirea acelor metode care pot conduce la finalităţile scontate, indiferent că sunt tradiţionale (clasice) sau moderne. De altfel, este imposibil să renunţi la tot ceea ce este considerat tradiţional pentru a adopta tot ceea ce este nou sau modern. Se impune astfel reluarea şi ,modernizarea” anumitor metode tradiţionale, care pot fi utilizate cu succes la lecţii.

Modernizarea metodelor tradiţionale presupune, în primul rând, înţelegerea specificului lor şi apoi încercarea de a le adapta nevoilor educaţionale actuale.

Principalul motiv pentru care metodele tradiţionale au căzut oarecum în desuetudine este faptul că acestea sunt centrate pe profesor sau cel mult pe cunoştinţe, în timp ce învăţământul modern are în centrul atenţiei elevul. Aşadar, prin utilizarea metodelor tradiţionale rolul activ revine profesorului, elevul având un rol pasiv.

Un alt neajuns al metodelor tradiţionale ar fi transmiterea informaţiei deja prelucrate, în formă finită şi în volum mare. Unele metode, precum expunerea sau prelegerea permit transmiterea într-un timp scurt a unui volum sporit de informaţii. Accentul cade astfel pe informaţie, nu pe procesul de învăţare, pe activitatea elevului. Elevii capabili şi silitori înregistrează informaţia, o prelucrează, o stochează şi înaintează spre succesul şcolar, în timp ce cei neinteresaţi de subiect, sau mai puţin dotaţi acumulează goluri în achiziţiile cognitive. Societate actuală este caracterizată ca fiind hiper informatizată: informaţii din diverse domenii pot fi accesate în fracţiuni de secundă, mai ales prin reţeaua Internet. În acest context, învăţământul actual nu se mai concentrează pe transmiterea informaţiilor şi reţinerea lor de 
către elev, ci pe formarea şi dezvoltarea capacităţilor de căutare, selectare, sintetizare şi utilizare a informaţiei.

Aspectele evocate anterior, alături de altele, conduc spre concluzia că, prin utilizarea excesivă a metodelor tradiţionale,

„elevii nu participă activ la dobândirea cunoştinţelor, nu-şi exersează capacităţile gândirii, ei sunt obligaţi să asculte disciplinaţi, atenţi, pasivi, chiar fără interes. Aceste metode predispun la superficialitate şi formalism în învăţare, la pasivitate, plictiseală, oboseală, neatenţie şi memorare mecanică" 20 .

O modernizare a metodelor tradiţionale presupune, în primul rând, schimbarea orientării în practica școlară: formaţia trebuie pusă înaintea instrucţiei, transmiterea şi asimilarea cunoştinţelor, deşi au o mare importanţă, trebuie să cedeze locul formării şi dezvoltării capacităţilor intelectual-acţionale şi a proceselor mintale ale elevului.

Schimbarea orientării metodologice presupune promovarea unor metode individuale, în funcţie de trebuinţele proprii şi ritmul propriu de învăţare, îndepărtându-se astfel pericolul metodelor nivelatoare şi uniformizatoare. Se obţine astfel o metodologie centrată pe elev, exprimată practic prin metodele activ-participative ${ }^{21}$.

Metodele didactice sunt „,bune”, adică eficiente, doar în măsura în care ele reuşesc să contribuie semnificativ la atingerea obiectivelor propuse. Pentru o înţelegere mai eficientă, metodele pot fi asimilate cu diferite drumuri care conduc către anumite localităţi (obiectivele), iar mijloacele didactice cu materialele din care sunt construite drumurile. Elevii parcurg drumuri diferite cu scopul de a învăța. Ei învaţă prin $a$ face, a observa, a asculta, a citi şi combinaţii ale acestor activităţii ${ }^{22}$.

Este demonstrat ştiinţific că oamenii nu-şi pot aminti materiale noi, dacă creierele lor nu sunt implicate în mod activ. Uneori se poate

\footnotetext{
${ }^{20}$ Maria Eliza Dulamă, Didactică geografică, Cluj-Napoca, Edit. Clusium, 1996, p. 71 .

${ }^{21}$ Ioan Cerghit, Metode de învăţământ..., p. 67.

${ }^{22} \mathrm{http}$ ://ctlactiveteaching.project.mnscu.edu/index.asp?Type=B_BASIC\&SEC $=\{6$ 74B0F0E-910E-43A2-9272-4F2DDFFF34CA
} 
să auzim cuvinte rostite de cineva, dar să ascultăm este cu totul altceva. Utilizarea metodelor şi tehnicilor active implică mai multe simţuri şi încurajează astfel elevii să se concentreze pe memorare şi înţelegere.

În practica educaţională actuală validitatea unei metode este judecată mai ales din perspectiva implicării sau participării (activizării) elevului la demersul didactic. Aşadar, putem afirma că modernizarea metodelor tradiţionale înseamnă, pe de o parte, transferarea rolului activ de la profesor la elev sau găsirea acelor soluţii prin care o metodă determină elevul să participe activ la învăţare, fie individual, fie în cadrul unui grup, iar pe de altă parte, stimularea motivaţiei intrinseci, învăţarea, pe termen lung, depinzând în mare măsură de motivaţia învăţării. Metodele ,pasive” trebuie problematizate, iar atenţia elevului trebuie captată şi stimulată, pentru a conduce la concentrare.

Unele dintre metodele de instruire sunt considerate ca promotoare ale unei învăţări în care elevul are un rol pasiv: povestirea, descrierea, prelegerea, expunerea, explicaţia. Modernizarea acestora înseamnă, pentru unii autori ${ }^{23}$, respectarea de către profesor a aspectelor metodice legate de comunicarea nonverbală şi paraverbală (mimică, gestică, intonaţie, atitudine corporală) specifice fiecărei metode, adaptarea conţinutului la particularităţile generale şi particulare ale elevilor, precum şi implicarea elevilor în utilizarea acestora: elevii pot fi solicitaţi să povestească sau să descrie în locul profesorului.

\section{Abordarea lecţiei de religie din perspectivă activizantă}

Metodele didactice sunt „,bune”, adică eficiente, doar în măsura în care ele reuşesc să contribuie semnificativ la atingerea obiectivelor propuse. Nu există o rețetă a succesului garantat în actul didactic, care să cuprindă un anume set de metode. Profesorul este cel care, la momentul potrivit, alege metoda care consideră că se potrivește cel mai bine cu specificul disciplinei, al conținutului abordat, al colectivului de elevi la care activează.

${ }^{23}$ Maria Eliza Dulamă, Didactică geografică..., p. 71-82. 
O metodă devine eficientă sau nu în funcție de diverși factori, printre care se numără și conținutul vizat, nivelul de școlaritate, specificul clasei de elevi, priceperea profesorului de a conduce activitatea didactică, frecvența utilizării metodelor activizante la clasă, la disciplina religie, dar și la alte discipline. La clasele la care învățătorul utilizează frecvent metode moderne, activizante, elevii înțeleg mai bine etapele metodei, comunică mai bine, se implică mai mult în activitate. La clasele la care nu se utilizează metodele activizante decât foarte rar (sau deloc), elevii par încântați de demersul didactic abordat, dar întâmpină dificultăți în înțelegerea sarcinilor, în comunicarea cu colegii, precum și în prezentarea rezultatelor muncii individuale sau de grup.

Eficiența activizării elevilor prin aplicarea unor metode didactice specifice este legată de particularitățile de vârstă ale elevilor și specificul colectivelor școlare. Metode precum cele centrate pe reflecție, observație și acțiune sunt mai greu de abordat la clasele primare și mai ales la nivelul achizițiilor fundamentale (SINELG, fishbowl, dramatizarea). Metodele de analiză, producere a ideilor și rezolvare a problemelor (Diagrama Venn-bula dublă, tehnica fishboning, cubul, brainstorming-ul, problematizarea) sunt folosite cu mai mult succes, dar în condițiile simplificării lor sau a implicării puternice a profesorului în activitatea didactică (explicarea amănunțită a sarcinilor, observarea atentă, stimularea participării tuturor elevilor, prevenirea apariției oricărui tip de conflict etc.). În general, la clasele primare, metodele interactive bazate pe activitatea practică au efect pozitiv asupra majorității elevilor. Există însă copii care au dezvoltate atenția și capacitatea de concentrare, așteptând ca profesorul să povestească, să descrie, să explice (metode expozitive).

În ciclul curricular de dezvoltare, mai ales la nivel gimnazial, elevii reacționează mai bine la predarea-învățarea prin metode de stimulare a creativității (brainstorming, explozia stelară, studiul de caz) și la cele fundamentate pe activitatea în grupuri (predarea-învățarea reciprocă, schimbă perechea, mozaicul, piramida).

Aceleași tipuri de metode enunțate anterior par a produce rezultatele cele mai bune spre finalul gimnaziului (clasele VII-VIII), 


\section{$15^{\text {th }}$ International Symposium on Science, Theology and Arts}

când sunt mai dezvoltate gândirea critică, capacitatea de analiză și producere a ideilor, dar și abilitățile de comunicare și interrelaționare. Tot acum elevii se implică mai eficient în activitățile de organizare a informațiilor prin reprezentări grafice (diagrama Venn, organizatorul grafic cronologic, al cunoștințelor, diagrama cauze-efect sau tehnica fishboning).

Conținutul învățării ce urmează a fi abordat în lecție este unul din aspectele cele mai importante în funcție de care profesorul își propune utlizarea unor metode. În general, conținuturile vizate de programele analitice pentru disciplina Religie la clasele pregătitoareVIII conțin noțiuni dogmatice, liturgice, istorice, morale și biblice.

Disciplina Religie face parte din aria curriculară Om și societate, iar cercetările au arătat că disciplinele din această arie, din cauza conținuturilor specifice, se pretează prea puțin la utilizarea metodelor moderne active și interactive. Mai exact, se lucrează adesea cu adevăruri/cunoștințe care nu pot fi supuse unei verificări directe din partea elevilor (adevărurile dogmatice, de exemplu). Așadar, în predarea noțiunilor din domeniul dogmatic se optează pentru metode expozitive precum expunerea sau povestirea, îmbinate cu descrierea și explicația.

La conținuturile din domeniul istoric, în etapa de predareînvățare a noilor cunoștințe, se pretează metode de comunicare orală (povestirea, descrierea, conversația etc.), metode de comunicare scrisă (lectura, studiul individual), precum și metode cu un mai puternic caracter activizant (SINELG, KWL, organizatorii grafici). În actualizarea, fixarea, sistematizarea și recapitularea cunoștințelor, se pot utiliza metode activizante precum brainstorming, conversația, problematizarea, cubul etc.

În abordarea noțiunilor din domeniul liturgic, trebuie valorificate cunoștințele dobândite în anii anteriori și experiența personală a elevilor, prin utilizarea unor metode și tehnici activizante: cubul, studiul de caz, mozaicul, diagramele-bula dublă, schimbă perechea etc.

Unitățile de conținut cuprinzând noțiuni biblice și de morală au un puternic caracter formativ, motiv pentru care, în cadrul lor pot fi 
utilizate o varietate de metode activizante, cum ar fi cele bazate pe reflecție (SINELG), pe observație (fishbowl), pe acțiune (studiul de caz, jocul de rol) sau cele centrate pe analiză (analiza SWOT, Diagrama Venn, bula dublă, tehnica fishboning), rezolvarea problemelor (problematizarea) și producerea ideilor (cubul, brainstorming-ul, explozia stelară).

Utilizarea unei metodologii didactice flexibile și diversificată are efecte benefice asupra procesului de învățare al elevilor, aspect observabil direct, din modul de participare a elevilor la demersurile didactice și analiza situației la învățătură, la disciplina religie, precum şi indirect, prin prisma deprinderilor, valorilor și atitudinilor formate, cu efect pozitiv în viața spirituală a copiilor.

Activitatea de predare-învățare este un demers flexibil, care permite profesorului abordarea și experimentarea unor tehnici diverse, care să contribuie în final la atingerea finalităților educaționale propuse. Se știe că o ,ispită" care pândește cadrul didactic constă în încorsetarea rigidă într-o anumită strategie didactică, bazată doar pe câteva metode de predare-învățare, care și-au demonstrat utilitatea în timp și respingerea altor alternative. Modernizarea metodologiei didactice impune folosirea de către profesorul de religie atât a metodelor moderne de predare-învățare, cu o puternică tentă activizantă, cât și integrarea cu succes a acestora în lecție, încă din faza de proiectare.

\section{Utilizarea metodelor activizante în tipuri diferite de lecție}

Metodele activizante sunt utilizate cu succes atât în lecția clasică, consacrată și specifică disciplinei Religie, cât și în modelele noi de organizare a lecției, care au la bază tocmai necesitatea implicării active a elevilor în procesul de învățare.

Modelul clasic de lecție care s-a impus în timp la nivelul disciplinei Religie în țara noastră este cel propus de distinșii profesori Monica și Dorin Opriș. ${ }^{24}$ In viziunea autorilor, tipurile de lecție diferă,

${ }^{24}$ Sebastian Șebu, Monica Opriș, Dorin Opriș, Metodica predării religiei, Alba Iulia, Edit. Reîntregirea, 2000, p. 195-200. 
în principal, în funcție de sarcina didactică dominantă. Se conturează astfel următoarele tipuri de lecție:

1. lecția de transmitere și însuşire de noi cunoștințe sau, după caz, de formare a deprinderilor intelectuale și practice;

2. lecția de recapitulare și sistematizare a cunoștințelor;

3. lecția de evaluare a cunoștințelor;

4. lecția mixtă, în care se îmbină armonios transmiterea și dobândirea de cunoștințe, formarea deprinderilor și priceperilor, recapitularea și sistematizarea, precum și evaluarea rezultatelor.

Lecția mixtă este utilizată cel mai des în predarea religiei, motiv pentru care prezentăm etapele după care se desfășoară:

1. momentul organizatoric;

2. verificarea cunoștințelor, capacităților și deprinderilor însușite în lecția anterioară;

3. pregătirea pentru lecția nouă;

4. anunțarea titlului lecției noi și prezentarea obiectivelor propuse;

5. comunicarea noilor cunoștințe;

6. fixarea noilor cunoștințe;

7. aprecierea, asocierea, generalizarea;

8. evaluarea;

9. activitatea suplimentară;

10. încheierea.

În cadrul acestui format de lecție, elevii pot fi activizaţi în oricare dintre etape. Momentul organizatoric, ca și încheierea, conțin rostirea/intonarea rugăciunii, moment în care majoritatea elevilor intră în atmosfera orei de religie. Dacă în aceste momente se rostește o rugăciune pentru un coleg bolnav sau pentru implorarea ajutorului divin în diferite situații (de exemplu în caz de inundații), se obține o mai bună „acordare a frecvențelor" colectivului de elevi.

Verificarea cunoștințelor se poate realiza prin diferite metode didactice activizante, mai ales dacă profesorul urmărește actualizarea unor informații necesare în predarea noilor cunoștințe. Dacă profesorul 
urmărește notarea uni număr de elevi, se recomandă utilizarea unor metode specifice de evaluare, care pot avea un caracter activizant, dar care nu fac obiectul prezentului studiu. Actualizarea cunoștințelor se poate realiza prin brainstorming, prin realizarea unor organizatoare grafice - diagrama Venn, bula dublă, organizatorul grafic cronologic/al caracteristicilor, cadranele, diagrama cauzelor și a efectelor (diagrama „os de peşte"), explozia stelară, ciorchinele, termenii cheie etc.

Comunicarea noilor cunoștințe se poate realiza prin metode tradiționale cărora se imprimă un caracter activizant (povestirea, descrierea, explicația, dezbaterea) sau prin metode moderne: SINELG, studiul de caz, cubul, Philips 6-6, cadranele, unul stă, trei circulă, schimbă perechea, piramida, predarea/învățarea reciprocă etc.

Fixarea cunoștințelor se realizează cel mai adesea prin dezbatere, problematizare, realizarea unor hărți conceptuale (organizatoare grafice), ciorchinele, tehnica lotus ș.a.

Aprecierea, asocierea și generalizarea urmărește realizarea unor judecăţi de valoare, sesizarea relevanței, actualităţii și aplicabilităţii unor informații pentru viața personală sau comunitară, esențializarea informațiilor, asocierea cu alte aspecte cunoscute. Acestea se realizează cel mai adesea prin expunere și conversație, iar într-o manieră mai modernă, prin realizarea uni cvintet, prin analizarea termenilor cheie etc.

Activitatea suplimentară este un aspect care este tot mai mult neglijat la disciplina religie, sub presiunea altor discipline din trunchiul comun, care răpesc suficient din timpul liber al elevilor. Activitatea suplimentară nu este obligatorie, deci nu se notează. Profesorul de religie nu trebuie să dea teme pentru acasă elevilor doar pentru că aşa se face, ci trebuie să ţină cont de mai multe aspecte: necesitatea, relevanţa şi cantitatea temei suplimentare, timpul liber al elevilor, care diferă în funcţie de clasă, nivel de şcolarizare, perioada din semestru ș.a.. Din perspectivă activizantă, activitatea suplimentară trebuie să conducă elevul spre cercetare, lectură critică, gândire, analiză, aplicare şi mai puţin spre memorare sau redare automată a unor informaţii. SINELG ca metodă de dezvoltare a lecturii critice, precum şi analiza SWOT se pot utiliza cu succes de elevi acasă. 
Modelul ERR (evocarea-realizarea sensului-reflecţia) a fost propus la finalul secolului trecut de J.L.Meredith şi K.S.Steel, pentru organizarea unei situaţii de învăţare sau a unei lecţii întregi, scopul fiind dezvoltarea gândirii critice şi integrarea creativă a informaţiilor şi conceptelor. Cele trei etape sunt într-o strânsă legătură, fiecare dintre ele vizând obiective de ordin cognitiv, afectiv şi voliţional ${ }^{25}$.

1. Evocarea urmăreşte actualizarea analitică şi sistematizarea experienţelor şi cunoştinţelor anterioare ale elevilor, prin diferite demersuri:

a. amintirea cunoştinţelor anterioare;

b. analizarea şi sistematizarea activă a cunoştinţelor anterioare;

c. stabilirea interesului şi scopului pentru explorarea subiectului.

2. Realizarea sensului urmăreşte înţelegerea noilor informaţii şi construirea sensului acestora, prin activităţi individuale sau de grup, care constau în realizarea unor sarcini didactice complexe, care să conducă la învăţare şi la comunicarea rezultatelor acesteia:

a. confruntarea cu noile informaţii sau experienţe;

b. implicarea cognitivă şi menţinerea interesului;

c. înţelegerea informaţiilor;

d. monitorizarea propriei înţelegeri.

3. Reflecţia asupra cunoştinţelor are drept scop consolidarea cunoştinţelor, reconsiderarea şi restructurarea informaţiilor pe care elevii le aveau despre subiectul vizat şi se realizează prin:

a. reformularea cunoştinţelor care conduce la restructurarea schemelor mintale ale elevilor, la dezvoltarea capacităţii de exprimare, la îmbogăţirea vocabularului şi la dezvoltarea capacităţii de analiză şi sinteză;

b. verificarea cunoştinţelor

${ }^{25}$ Dorin Opriş, Monica Opriş, Metode active de predare-învăţare. Modele şi aplicaţii la religie, Iaşi, Edit. Sf. Mina, 2006, p. 13. 
Modelul ERR de organizare a lecţiei de religie are caracter activizant pentru elevi, prin utilizarea unui set de metode moderne, specifice fiecărei etape. Prezentăm o parte din metodele activizante ce pot fi utilizate cu succes în cele trei etape ale lecţiei.

1. Metode utilizate în evocarea cunoştinţelor anterioare: Brainstorming, explozia stelară, ciorchinele, stabilirea succesiunii evenimentelor, termenii cheie etc.

2. metode utilizate în realizarea sensului: Studiul de caz, cubul, SINELG, Philips 6-6, tehnica 6-3-5, cadranele, organizatorul grafic, diagrama cauzelor şi a efectului, tehnica lotus, pălăriile gânditoare, metoda predării/învăţării reciproce etc.

3. Metode utilizate în reflecţie: cvintetul, jocul de rol, întrebările, linia vieţii, eseul dintr-un cuvânt etc.

Modelul PAR este propus de către Geoff Petty, unul dintre experţii britanici în domeniul metodelor de predare. Profesor de fizică la origine, Petty s-a remarcat la nivel naţional în Marea Britanie prin calitatea sa de formator şi mai ales de autor al unor lucrări de specialitate, dintre care „Teaching Today. A Practical Guide” a ajuns la ediţia a IV-a. Autorul şi-a căpătat notorietate prin felul de a explicita problematica predării şi învăţării, într-o manieră simplă, pe înţelesul tuturor, dar într-un mod viu, care inspiră pe practicieni.

Abordarea sa are la bază teoria constructivistă a învăţării, conform căreia învăţarea implică în mod automat construirea unor înţelesuri proprii, ceea ce implică realizarea unor conexiuni între neuroni. Învăţarea se fundamentează astfel pe ceea ce noi ştim deja. Când o persoană învaţă ceva, instantaneu se produc unele transformări la nivelul creierului, astfel încât învăţarea este un proces activ. ${ }^{26}$ Pasivismul în învăţare înseamnă de fapt neînvăţare. Cei trei paşi propuşi de autor pentru realizarea unei secvenţe de lecţie sau chiar a unei lecţii întregi sunt: Prezintă-Aplică-Recapitulează.

Prezentarea este o etapă de orientare în care se urmărește înţelegerea noului material. A ști înseamnă în primul rând a înțelege. În

${ }^{26}$ www.geoffpetty.com 


\section{$15^{\text {th }}$ International Symposium on Science, Theology and Arts}

această etapă sunt actualizate noțiuni din lecțiile anterioare, necesare pentru înţelegerea noului material și se stimulează motivația învăţării, insistându-se asupra relevanței, importanței și valorii învăţării noului material. Se prezintă obiectivele propuse și se pot adăuga și altele, în funcție de interesele elevilor. Introducerea noilor cunoștințe este momentul cel mai important al acestei etape și se realizează, de preferință, prin metode active și interactive și cât mai puțin prin metode expozitive.

Prezentarea noului material se poate desfășura prin strategii specifice: predarea prin întrebări, prezentarea unui material audiovideo, metoda demonstraţiei, bulgărele de zăpadă, brainstorming, mozaicul, controversa academică etc.

Aplicarea este cea de a doua etapă în cadrul predării prin modelul PAR. În cadrul etapei, elevii pun în practică ceea ce tocmai au învățat și acest lucru este posibil prin utilizarea unor metode activizante, precum acordarea unor sarcini practice, oferirea de răspunsuri la întrebări, dezbatere, decizii - decizii, problematizarea, evaluare critică a unor exemple etc.

În etapa de recapitulare se sintetizează și se clarifică ceea ce se presupune că a fost învățat. Este faza în care se obține feed-back-ul activității și se pot face intervenții ameliorative. Printre strategiile didactice activizante care pot fi utilizate în această etapă se numără și creare de hărți conceptuale, diagrame sau postere, teste scurte etc.

Autorul precizează că acest model de predare trebuie să fie flexibil: poate fi aplicat pentru o lecție întreagă sau doar pe una sau mai multe secvențe ale acesteia, iar fazele de prezentare și aplicare pot alterna de mai multe ori în aceeași lecție (de exemplu, când se dorește introducerea și consolidarea mai multor concepte), fiind urmate de etapa recapitulării.

Fiecare dintre cele trei faze are o anumită pondere în cadrul activităţii; astfel prezentarea ocupă maxim 35\% (ea necesită alocarea unui timp suficient de mare pentru introducerea noilor noţiuni); aplicarea deţine cea mai mare pondere- minim 60\% - deoarece elevii aplică ceea ce au învăţat, fixându-şi astfel noile conţinuturi; recapitularea se realizează în minim 5\% din timpul activităţii, fiind 
momentul în care primim cel mai puternic feedback privitor la asimilarea noului material.

Se observă că acest model poate fi utilizat cu ușurință la disciplinele cu un puternic caracter practic și experimental (fizică, chimie, biologie etc.). El poate fi adaptat însă și utilizat și în discipline la care se lucrează mai mult cu noțiuni teoretice (disciplinele din cadrul ariei curriculare Om și societate, din care face parte și religia).

Managementul lucrului in echipă, al studiului individual, al practicii, conform modelului de predare PAR, poate fi schematizat astfel :

\begin{tabular}{|c|c|c|c|c|c|c|}
\hline $\begin{array}{l}\text { Fixarea } \\
\text { sarcinii de } \\
\text { lucru } \\
\text { Sarcina de } \\
\text { lucru trebuie } \\
\text { să fie clară și } \\
\text { în scris. } \\
\text { Elevilor li se } \\
\text { dau roluri } \\
\text { individuale. }\end{array}$ & $\rightarrow$ & $\begin{array}{l}\underline{\text { Elevii }} \\
\underline{\text { lucrează }} \\
\text { Se poate } \\
\text { lucra } \\
\text { individu } \\
\text { al sau pe } \\
\text { grupe }\end{array}$ & $\rightarrow$ & $\begin{array}{l}\text { Feedback- } \\
\text { ul elevului } \\
\text { Profesorul } \\
\text { primește } \\
\text { feedback } \\
\text { din partea } \\
\text { elevilor } \\
\text { referitor la } \\
\text { descoperiri } \\
\text { le acestora }\end{array}$ & $\rightarrow$ & 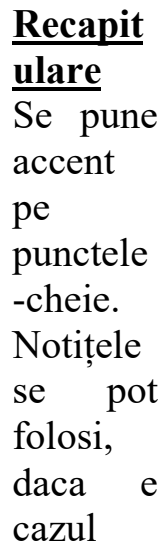 \\
\hline
\end{tabular}

\section{Verificare și corectare}

Profesorul verifică atenția elevilor și desfăşurarea activităţii

Managementul activității modelul PAR

\section{Concluzii}

Una dintre marile provocări ale societăţii contemporane pe plan pedagogic este centrarea demersului didactic pe elev, prin stimularea capacităţilor creative, volitive, atitudinale, critice şi acţionale. Dacă în 


\section{$15^{\text {th }}$ International Symposium on Science, Theology and Arts}

pedagogia clasică elevul apare mai mult ca spectator în actul didactic, în orientarea actuală, el devine co-participant şi chiar principalul actor al propriei formări. Pedagogia modernă a demonstrat că învăţarea este mai profundă şi mai eficientă în măsura în care elevul este activ, participând efectiv la actul didactic şi nu doar observând, ascultând, urmărind.

O cale de a-i activiza pe elevi ar putea fi dezvoltarea de către profesor a unui stil didactic flexibil, modern şi creativ, prin aplicarea unor strategii didactice interactive. Acest obiectiv devine o adevărată provocare mai ales pentru cadrele didactice care nu au avut inserată această direcţie în formarea iniţială. În faţa acestei provocări se conturează două tipuri de atitudini: respingerea a tot ceea ce este nou, modern, activ-participativ în favoarea a tot ceea ce este considerat „tradiţional" sau, din contră, desconsiderarea ,tradiţionalului" în favoarea „modernului”. Mult mai constructivă este calea de mijloc: utilizarea atât a metodelor moderne, cât și a celor tradiţionale, care au un caracter activizant și formativ.

Profesorul de religie captează atenția elevilor când este inovativ: rutina poate conduce la plictiseală. Există momente în cadrul lecției obligatorii (salutul, notarea absențelor etc.), dar există și momente care pot fi înlocuite sau inversate. Elevii apreciază când profesorul alege un alt mod de desfășurare a lecției de religie. Dascălul este cel care judecă valoare educativă și eficiența diverselor strategii didactice și le adaptează la specificul disciplinei. În lecțiile în care se predau noțiuni de morală sau de liturgică pot fi utilizate cu succes metode bazate pe analiza unor situații și aplicaţii practice.

Locul desfășurării lecției este de asemenea important pentru implicarea elevilor. În măsura posibilităţilor, este recomandat ca ora de religie să se desfăşoare într-un spațiu specific - biserică, capelă, paraclis, cabinet de religie.

Rostirea sau intonarea rugăciunii este pentru elevi poate momentul cel mai intim și mai formativ al orei de religie. Este clipa în care ei părăsesc alte preocupări și realizează aceeași activitate. Pericolul rutinei amenință însă și folosul rugăciunii, de aceea este recomandat ca, în anumite momente, profesorul să aștepte îndemnul 
spre rugăciune ca venind de la elevi. De asemenea, în cazul unor situații conflictuale evidente la începerea lecției, ar fi potrivită mai întâi o discuţie cu elevii implicaţi sau o încercare de aplanare și apoi rostirea rugăciunii.

\section{Bibliografie}

- *** Dimensiuni ale educației la început de mileniu-studii, articole, soluții didactice, Iași, Edit. Infoed XXI, 2007.

- Breben, Silvia, Gongea, Elena, Ruiu, Georgeta, Fulga, Mihaela, Metode interactive de grup-ghid metodic, Craiova, Edit. Arves, 2002.

- Cerghit, Ioan, Metode de invățământ, ediţia aIV-a, Iaşi, Edit. Polirom, 2006.

- Dancsuly, A., Ionescu, M., Radu, I., Salade, D., Pedagogie, București, Edit. Didactică și pedagogică, 1979.

- Dulamă, Maria Eliza, Didactică geografică, Cluj-Napoca, Edit. Clusium, 1996.

- Ionescu, Miron, Clasic și modern în organizarea lecției, Cluj-Napoca, Edit. Dacia, 1972.

- Ionescu, Miron, Radu Ioan (coord.), Didactica modernă, Cluj-Napoca, Edit. Dacia, 1995.

- Nicola, Ioan, Pedagogie, Bucureşti, Edit. Didactică şi Pedagogică, 1994.

- Oprea, Crenguța-Lăcrămioara, Strategii didactice interactive, ediția a IIa, București, Edit. Didactică și pedagogică, R.A., 2007.

- Opriş, Dorin, Opriş Monica, Metode active de predare-învăţare. Modele şi aplicaţii la religie, Edit. Sf. Mina, Iaşi, 2006.

- Pânișoară, Ion-Ovidiu, Comunicarea eficientă, ediția a III-a, Iași, Edit. Polirom, 2006.

- $\quad$ Romiţ̧ă, Iucu, Instruirea şcolară, Iaşi, Edit. Polirom, 2001

- Şebu, Sebastian, Opriş, Monica, Opriş, Dorin, Metodica predării religiei, Alba Iulia, Edit. Reîntregirea, 2000.

Adrese web

- $\quad$ http://ctlactiveteaching.project.mnscu.edu/index.asp?Type=B BASIC\&S $\mathrm{EC}=\{674 \mathrm{~B} 0 \mathrm{~F} 0 \mathrm{E}-910 \mathrm{E}-43 \mathrm{~A} 2-9272-4 \mathrm{~F} 2 \mathrm{DDFFF} 34 \mathrm{CA}\}$

- $\quad$ www.geoffpetty.com 